総説

\title{
男性型脱毛症と育毛有効成分
}

\author{
横山大三郎 \\ ライオン(㹯)生物化学センター \\ （干256 神奈川県小田原市田島 100）
}

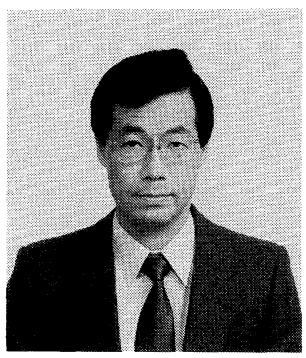

\section{Male Pattern Baldness and Hair Growth Promoters}

\author{
Daisaburo YoKOYAMA \\ Biological Science Research Center, Lion Corporation \\ (100 Tajima, Odawara-shi, Kanagawa-ken, T256)
}

\begin{abstract}
This article reviews about hair growth and its cycle, male pattern baldness and its cause, hair growth promoters, and the evaluation methods for such promoters. The mechanism of hair growth and causes of male pattern baldness are still not clear, but recent studies on hair growth are bringing up some interesting and important facts. New discoveries on energy metabolism, interaction between hair matrix and dermal papilla, and action of androgens are discussed along with their application to the production of new hair growth promoters. A new hair growth promoter, monopentadecanoylglycerol (PDG), is discussed in relation to its effect for promating the energy metabolism.
\end{abstract}

\section{1 はじめに}

現在，我が国で市販されている育毛・湌毛剂は医薬品 および医薬部外品あわせて 130 種以上に及ぶと言われて いる。その市場は 300〜400 億円という規模に至り， 年々拡大しつつある。この背景には，ストレスの増大に よる若年〜壮年層での脱毛症の増加等があると考えられ る。この傾向は今後も続き, 育毛剂に対する社会的期待 はますます高まるであろう。

脱毛症には原因や症状によっていろいろな種類のもの があるが，その大半を占めるのは男性型脱毛症（いわゆ る若はげ）である。これに対する従来の育毛剂は, 経験 による民間薬的なもの，もしくは対症療法的なものが多 くを占めており，有効性の面で充分之は言えないのが現 状であった。しかし近年, 毛の成長や男性型脱毛症に関 する基礎的研究の進展により, 新しい知見が見いだされ つつあり, それに基づく新しい観点からの育毛有効成分 の開発が試みられている。

本稿では，まず毛の成長と男性型脱毛症の基礎知識に ついて最近の知見も含めて振り返り, 次に育毛剂の有効 成分, 育毛効果の評価法について述へ，最後に新規育毛 有効成分の事例として, 著者らが開発したペンタデカノ イルグリセリン (ペンタデカン酸グリセリド ; PDG) の 作用について紹介したい。

\section{2 毛の成長とヘアサイクル}

\section{$2 \cdot 1$ 毛の成長}

頭髪は通常 10 万本あり, 平均的には 1 か月に約 1 $\mathrm{cm}$ 伸びる。皮膚上に伸びた部分を毛幹, 皮膚内に埋も れた部分を毛根と言う。毛根は手包という組織でさや （䩗）状に囲まれており，成長期の毛では下端が䐍張し て毛球を形成している。毛包の基本的構造を Fig.-11) に示す。

これらの構造のうち, 毛の成長に重要な役割を果たし ている部分は毛球 (hair bulb) に存在する毛母 (hair

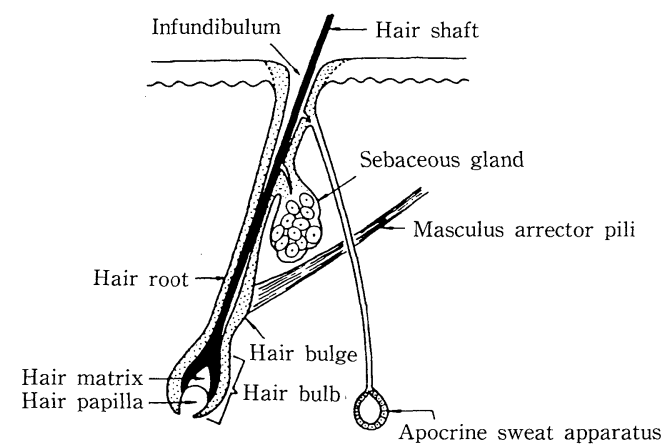

Fig. -1 Stracture of hair follicle ${ }^{1)}$. 
matrix) と毛乳頭 (hair papilla) である。毛母細胞は 表皮性の細胞で, 分裂 $\rightarrow$ 分化（角化）の過程を経て自ら 毛を形成する。この細胞は分裂速度が極めて高く ${ }^{2)}$, 七 卜のあらゆる組織細胞のうちで最も活発に分裂, 分化し ながら, タンパク質の生合成とケラチン化を行ってい る。その結果, 頭髪として $1 \mathrm{~d}$ に生産されるタンパク量 は, 約 $400 \mathrm{mg}$ に相当すると推測されている3)。毛乳頭 細胞は真皮性の細胞で，毛乳頭毛細血管から栄養分を取 り込み, 毛母細胞に供給する役割を担っていると考えら れる。しかしそれだけでなく，この両者の間には相互作 用 (毛母-毛乳頭相互作用) が存在し，これが毛の成長 や次に述べるへアサイクルに深く関与することが最近の

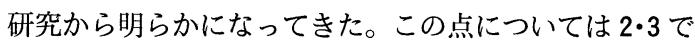
述べる。

\section{$2 \cdot 2$ ヘアサイクル}

毛は成長 $\rightarrow$ 休止 $\rightarrow$ 脱毛を繰り返しており，これをへア サイクル (毛周期) という。Fig. - 2 にその模式図を示 す。一般に動物はこのヘアサイクルが同調しており, 一 斉にあるいは波状に毛の生え変わりが起こる。ヒトの場 合は 1 本 1 本が各々独自のへアサイクルを有している。 すなわち, 2 7 年の成長期 (anagen) の後, 約 3 週間 の中間期 (catagen) を経て休止期 (telogen) となり, 約 3 か月後に抜け落ちる。しかし, この時点ですでに新 毛が発生しており, 再び成長期毛一と成育する。従って 正常な人の場合, $1 \mathrm{~d}$ に 50 100 本程度の抜け毛があっ ても頭髪全体では成長期毛が 85〜90\% \%占めており， 常にフサフサしていることになる。

このへアサイクルが何らかの原因により正常に回転し なくなり，成長期が維持できなくなって休止期 $\rightarrow$ 脱毛へ と進んでしまうと, 脱毛症の症状が現れてくるというこ とになる。では, ヘアサイクルはいったいどのようなメ カニズムで制御されているのだろうか，ということにな ると，いまだにほとんど解明されていないと言っても過 言ではない。

\section{$2 \cdot 3$ 毛母-毛乳頭相互作用}

毛成長あるいはへアサイクルの制御機構解明のため,

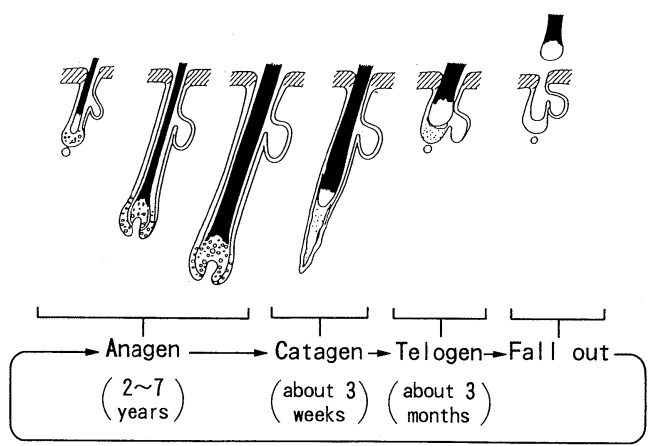

Fig.-2 Diagram of hair cycle.
毛母-毛乳頭相互作用の研究が近年盛んに行われてい る。そのきっかけとなったのが Oliver ら ${ }^{4)}$ の研究であ る。彼らはラットのヒゲから摘出した毛乳頭を耳介の真 皮内に移植し, 約 1 か月で毛包構造の形成とヒゲ型毛幹 の発生を認めた。Jahoda ら ${ }^{5)}$ は, ラットのヒゲ毛包の 下部 $1 / 2$ を切除して, その直下に培養毛乳頭細胞（1３ 代）のペレットを移植し, 毛球部の再生と毛幹部の発生 を認めた。しかし, 皮膚瀻維芽細胞や培養継代数を重ね た（10１5 代）毛乳頭細胞のペレットでは，このよう な現象は起こらなかった。これらのことは, 毛乳頭細胞 が表皮細胞に働きかけて毛包組織を誘導する能力を持っ ていることを示している。

Arase ら ${ }^{6)}$ は, 毛乳頭を除去したヒト毛包と毛乳頭 をコラーゲンゲル内で組み合わせ培養し, 毛母由来上皮 細胞が円柱状の構造物を形成しながら毛乳頭に向かって 增殖, 伸長して, 毛乳頭を取り囲む現象を観察した。こ のことは, 毛乳頭細胞が毛母細胞を引き寄せる因子を産 生, 分泌していることを示している。Hirai ら ${ }^{7)}$ はマウ ス胎児の毛包形成に対する表皮細胞や真皮細胞の影響を 組み合わせ培養実験により検討し，真皮細胞を単層では なく一塊培養することによって産出される毛包形成因子 エピモルフィン (EPI) を見いだした。神藤ら ${ }^{8)}$ は, ラット毛包器官培養法により各種サイトカイニンや増殖 因子による毛の伸びを観察し, 肝細胞増殖因子 (HGF) の毛幹伸長促進活性を示した。

これらの知見から, 毛包の新生, 誘導や毛の成長, へ アサイクルの制御に EPI や HGF などの因子が樑く関 与しているものと考えられている。そして, それらは毛 乳頭細胞由来のシグナルであり, 毛乳頭細胞と毛母細胞 の接着, 連結を通じて毛母細胞に伝わって様々な調節を している可能性が高いと考えられる。

\section{3 男性型脱毛症とその原因}

\section{$3 \cdot 1$ 男性型脱毛症とは}

男性型脱毛症の症状は, 何らかの原因によってへアサ イクルのバランスが失われ, 成長期の期間が短縮して休 止期毛の此率が増加し, 毛髪が軟毛 (うぶ毛) 化すると いうものである。組織学的には, 成長期毛毛包のサイズ は健常頭皮のそれと比べて小さく, 毛乳頭の発達も悪 く, 毛包をとりまく毛細血管網も減少している。つま り, 男性型脱毛症は毛包の数が減少するのはなく, 毛包 のサイズが減少することにより, 硬毛の軟毛化が起こる という現象である。

この症状は思春期以降, だいたい $20 〜 30$ 才代から始 まり, 前頭部, 頭頂部にわたって徐々に進行していく が, 側頭部や後頭部の下部には及ばない。進行の仕方に はいくつかの病型 (パターン) があるのが特徴である。 Fig. $-3^{9)}$ に男性型脱毛症の典型的な病型およびステー 


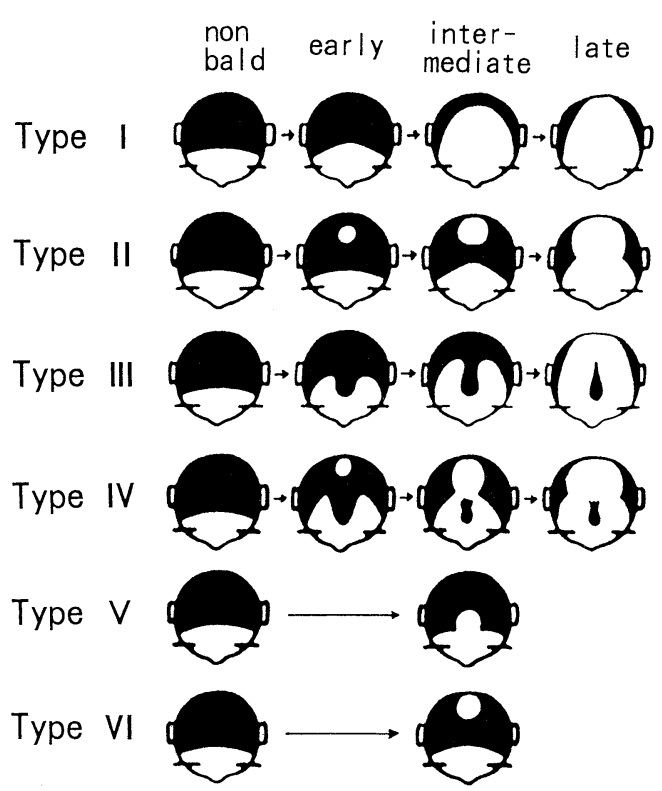

Fig.-3 Classification of male pattern baldness $\left(\right.$ Ogata $\left.^{9)}\right)$.

\section{ジを示す。}

\section{$3 \cdot 2$ 男性型脱毛症の原因}

男性型脱毛症の原因については, 1940 年代の Hamilton ${ }^{10)}$ による男性ホルモン (androgen) に関する研究 がよく知られている。この研究によると, 脱毛症の進行 は去勢により停止し, 男性ホルモンの投与により再び進 行する。また, 思春期の男性を去勢すると脱毛症は起き ず，男性ホルモンを投与すると脱毛症の家系では脱毛症 が起きる。すなわち, 男性ホルモンと遺伝的素因が男性 型脱毛症の発症に密接に関連していることを明らかにし た。

その後, 男性ホルモンに関する研究が各方面で盛んに 行われ，代謝や作用発現についてかなり明らかになって

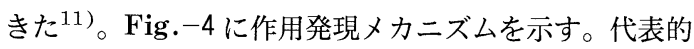

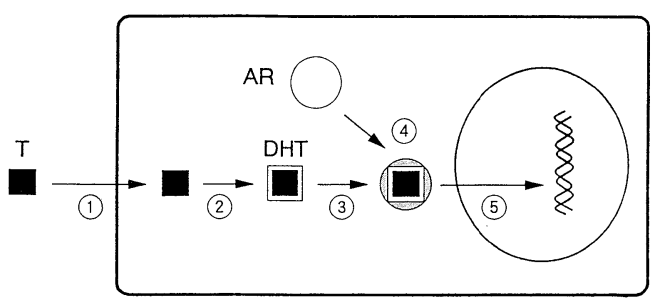

$\mathrm{T}$ : testosterone, DHT : dihydrotestosterone, AR : androgen receptor, (1)transference into cell, (2) $5 \alpha^{-}$ reductase reaction, (3) binding to receptor, (4) change in configuration (activation), (5)transference into nucleus, activation of transcription

Fig.-4 Mechanism of action of androgens.
な男性ホルモンであるテストステロンは細胞内で酵素 (5 $\alpha$-リダクターゼ) により代謝されてジヒドロテスト ステロン $(\mathrm{DHT})$ に変換され, これが男性ホルモンレセ プターと結合して核内の遺伝子と結びつき, タンパク合 成を介して様々なホルモン作用を発現する。この男性ホ ルモン作用の発現機構の解明はまだまだ不充分であり, 特に毛の成長や男性型脱毛症との関連において, その詳 細はいまだにあまり解明されていないと言える。

しかし最近の研究から, 毛母細胞には男性ホルモンレ セプターは発現していない ${ }^{12)}$ が, 毛乳頭細胞はこのレ セプターを持っており, レセプターの活性 ${ }^{13)}$ と $5 \alpha$-リ ダクターゼの活性やタイプ14)の差が毛包の男性ホルモ ン依存性に深く関与していることが示されている。ま た, 男性ホルモンはまず毛乳頭細胞に作用し, 前述した 毛母-毛乳頭相互作用を介して毛母細胞に作用すること も示唆され ${ }^{15)}$, 毛包における男性ホルモン作用の解明 が進展しつつある。

これまで述べてきたように, 男性ホルモンが男性型脱 毛症に密接に関連していることは間違いないと考えられ るが，そのほかの原因として従来から血液循環不良説, 栄養障害説, ストレス説などの諸説 ${ }^{16)}$ が唱えられてい る。しかし，これらはいずれも明確なものではなく，一 つの説ですべてを説明するには無理があるというのが実 情である。

\section{$3 \cdot 3$ 男性型脱毛症と毛包エネルギー代謝}

著者らは, 男性型脱毛症と毛包エネルギー代謝の関係 に着目し, 基礎的研究を行ってきた。その背景には, 毛 包では毛母細胞が分裂, 分化をするために多量のエネル ギーが必要亡されること ${ }^{17)}$, ヘアサイクルの変化に 伴って毛包エネルギー代謝系の酵素活性が変化するこ と ${ }^{18)}$ など, 毛包エネルギー代謝に関する生化学的研究 の進展があった。

著者らは渡辺と ${ }^{19)}$ の共同研究において, 男性型脱毛 症の進行に伴い毛包のエネルギー代謝系酵素, 特にグル コース 6 リン酸脱水素酵素 (G 6 PDH) の活性低下を認 めた (Fig. -5)。また, 乳酸脱水素酵素やイソクエン酸

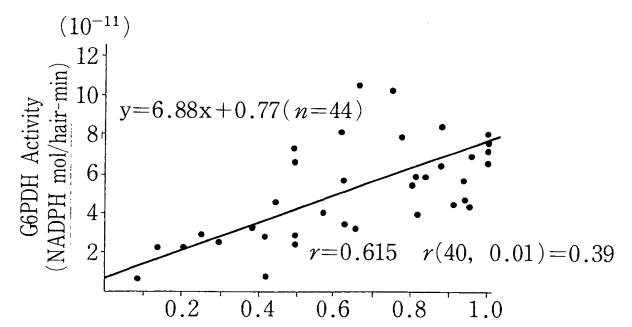

Ratio of anagen hair (anagen hairs/total removed hairs)

Fig. -5 Correlation between ratio of anagen hairs and G6PDH activity in hair follicle of male pattern haldness. 
脱水素酵素の活性も低下しているという報告もある ${ }^{20)}$ 。 これらのことから, 男性型脱毛症には毛包エネルギー代 謝活性の低下が深く関与しており，これを改善すること が育毛の重要なポイントであると考えられる。

\section{4 育毛剂の有効成分}

\section{$4 \cdot 1$ 育毛剂の有効成分}

従来の育毛剂は栄養補給剂, 血管拡張剤, ホルモン 剂, 抗炎症剤, 殺菌剂, その他天然物等をいろいろと組 み合わせて配合したものである。その代表的な配合成分 と効能を Table-1 に示す。

栄養補給剤は，毛母細胞に充分な栄養分を供給し，代 謝系を活性化させることを目的に配合される成分であ り, パントテン酸等のビタミン類や各種アミノ酸類が用 いられている。血管拡張剂は, 毛包の血管を拡張して血 流量を増加させ, 栄養分の供給を活発にさせることを目 的に配合される成分であり, 酢酸トコフェロール, 塩化 カルプロニウム, センブリエキスの他, トウガラシチン キ等の刺激剤も用いられている。ホルモン郕は, 男性ホ ルモンの作用を緩和することを目的に配合される成分で あり, エチニルエストラジオール等の女性ホルモンが用 いられているが, その配合量は副作用の点から極微量に 制限されている。抗炎症剤・殺菌剂は, 頭皮の状態を改 善し, 清潔に保つことを目的に配合される成分である。

\section{$4 \cdot 2$ 新しい観点からの有効成分}

従来の育毛剂には, 上述の観点からいろいろな成分が 配合されているが, 毛の成長メカニズムや男性型脱毛症 の発症メカニズムには未解決な点が多く, これらの成分 の有效性に対する評価も低いのが現状である。

最近の新しい傾向としては, 皮脂抑制成分の開発があ げられる。男性型脱毛症の人は頭皮皮脂分泌量が多いと 言われており，過剩な皮脂が男性型脱毛症の原因の一つ であるという考え方で, 皮脂抑制成分が研究されてい
る。しかし, 過剩皮脂が原因なのか結果なのかははっき りしない面がある。また, 新しい保湿成分の開発も行わ れているが，頭皮の保湿と毛の成長や男性型脱毛症との 関係もあまり明確ではない。

一方, 男性ホルモンの作用をきっ抗的に抑制する抗男 性ホルモン剂や活性型男性ホルモン（ビヒドロテストス テロン) を生成する酵素 ( $5 \alpha$-リダクターゼ) の阻害剂 等の研究も盛んに行われている。男性ホルモンが男性型 脱毛症に深く関与していることは間違いないので, 男性 ホルモン作用を抑えることができれば有望な有効成分と 成り得るが，全身的な作用を示しては副作用の問題が生 じる。いかに局所的に，すなわち毛包に特異的に作用す る成分を見いだすかが大きな課題と言えよう。

著者らは先にも述べたように，毛包エネルギー代謝に 着目し, その改善という観点から, 新規有効成分 PDG

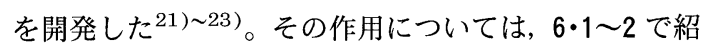
介する。

\section{5 育毛効果の評価法}

\section{$5 \cdot 1$ in vitro 系}

無細胞系 : 抗男性ホルモン作用の検討や毛成長の生化 学的検討には醭素レベル, レセプターレベル等, 無細胞 系での研究が有用である。抗男性ホルモン作用の検討に

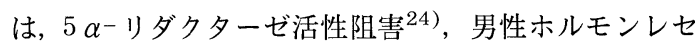
プター結合阻害 ${ }^{25)}$ などの評価法が用いられる。また， エネルギー代謝 ${ }^{18) ~ 20)}$ や角化 ${ }^{26)}$ に関与する酵素の活性 を測定し, 毛の成長との関連性を生化学的に検討しょう とする試みもよく行われている。

細胞培養系 : 毛包を構成する細胞を培養し，增殖や分 化に対する影響を評価する方法である。真皮性の細胞で ある毛乳頭由来緘維芽細胞の培養系 ${ }^{27), 28)}$ はすでに確立 されており，多くの研究に用いられてきた。上皮性の細 胞については, 各種培養法の確立が精力的に行われてい

Table-1 Ingredients of commercial hair products.

\begin{tabular}{l|l|l}
\hline \multicolumn{2}{c|}{ Classification } & \multicolumn{1}{c}{ Ingredient } \\
\hline \multirow{2}{*}{$\begin{array}{l}\text { Hair } \\
\text { nutrition }\end{array}$} & Vitamins & $\begin{array}{l}\text { Calcium pantothenate, Vitamin A acetate, Pantothenyl } \\
\text { alcohol, Pyridoxine hydrochloride }\end{array}$ \\
\cline { 2 - 3 } & Amino acids & Methionine, Serine \\
\hline Vasodilators & $\begin{array}{l}\text { Tocopherol acetate, Carpronium chloride, Ginseng, Swertia } \\
\text { extract, Capsicum extract, } l \text {-Menthol }\end{array}$ \\
\hline Hormones & Ethynylestradiol, Estradiol dipropionate \\
\hline Anti-inflammatory drugs & Diphenylhydramine hydrochloride, Glycyrrhizin \\
\hline Bactericidal substance & Benzalkonium chloride \\
\hline Medicinal plant extract & Cantharides tincture, Hinokitiol, Cepharanthin \\
\hline
\end{tabular}


る。トリプシンやディパーゼによる真皮成分の分離 ${ }^{29}$ やCa イオン濃度による分化のコントロール 手法が可能となり, 外毛根しょう(鞘)由来細胞 ${ }^{31}$ )等の 毛包上皮細胞の培養法が報告されている。また, 細胞間 の相互作用を検討するための同時培養法 ${ }^{32)}$ 等も報告さ れている。

器官培養系 : 毛包組織全体を培盖し, 毛の成長や組織 形態などに対する影響を評価する方法であり, 細胞培養 に比べてより総括的な評価が可能となる。これまでに, マウス ${ }^{33)}$ あるいはヒト ${ }^{34)}$ の毛包を用いた器官培養法が 報告されており, 無血清培地中での成長因子の評価等も 可能となってきた。しかし, 現段階では培養可能期間が 7 $10 \mathrm{~d}$ 程度と短く, ヒトで㕕毛効果が現れるのに $3 \sim 6$ か月かかることを考えると, 現状では有効性の評価より はむしろ毛の成長メカニズムの解明に有用な手段之考え られる。

\section{$5 \cdot 2$ 動物を用いた評価法}

動物実験系での評価では, 動物の種類によってへアサ イクルの特性に違いがあることに注意すべきである。評 価すべき観点に応じて用いる動物を選定し，そのへアサ イクルの特性をうまく利用することが重要となる。

C $3 \mathrm{H}$ マウス ${ }^{35)}$ : C $3 \mathrm{H}$ マウスは毛周期が生後 $45 \mathrm{~d}$ から $95 \mathrm{~d}$ まで休止期であることが知られている。この 休止期にある背部毛をてい(別)毛した後被験物質を塗布 し, 剃毛部の面積に対する毛再生部の面積の割合から, 再生速度に対する被験物質の影響を評価する方法であ る。

C 57 BL マウス ${ }^{36)}$ : C 57 BL マウスは抗男性ホルモ ン作用の評価によく用いられている。脱毛処理後テスト ステロンを作用させることにより毛の再生が阻害される ので, 被験物質を塗布することにより, その再生阻害に 対する影響を評価する方法である。

モルモット22),37) : モルモットのヘアサイクルはヒト と同様に 1 本 1 本の毛が独自の周期を営むが, 毛刈りす ることにより休止期毛は急速に活性化されて成長期へ移 行する。この特性を利用し, 毛刈りによって成長期に均 一化した後, 被験物質を塗布し, 毛の成長速度（長さ, 重量）に対する影響を評価する方法である。

ウサギ22),37：ウサギのへアサイクルは一定期間（約 2 か月）ごとに成長期と休止期を繰り返す。休止期の初 期から被験物質を㙦布し, 成長期へ移行する速度に対す る影響を評価する方法である。マウスなどに比べて大き いため 1 匹で $6 \sim 8$ 検体の塗布が可能であり, 固体ごと に無塗布部，対照部との比較が可能である。

\section{$5 \cdot 3$ ヒトによる評価法}

これまで述べてきた評価法は有効成分の探索段階やス クリーニングには有用であるが, 最終的にはヒト（男性 型脱毛症）による実用試験によって効果を判定する必要
がある。通常, 皮膚科専門医師による臨床的診断によっ て判定されるが，それを補助する意味で定量的評価の実 施が極めて重要である。代表的な定量的評価法として は, トリコグラム (成長期毛の比率の評価 $)^{38}$, 毛髪数 の測定 ${ }^{39)}$, 抜け毛数の測定 ${ }^{40)}$ などがある。また, コン ピューター画像解析法を用いた成長速度の測定法 ${ }^{41)}$, 毛髪直径の測定法 ${ }^{42)}$ なども報告されている。これらの 中には定量性や被験者への負担などの点で問題点の残る ものもあり, 既存手法の改良や新手法の開発が期待され る。

\section{6 新規有効成分 PDG の育毛作用}

先にも述べたように, 著者らは毛包エネルギー代謝に 着目し, その改善による毛母細胞の賦活という観点か

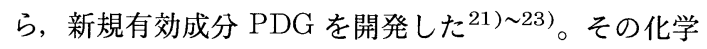
構造を Fig.-6に示す。PDG は炭素鎖長 15 の脂肪酸の モノアシルグリセリンであり, 奇数鎖長脂肪酸の代謝特 性によって, エネルギー代謝の低下した男性型脱毛症の 毛包においてエネルギー産生を促進する作用を有すると 考えられる。ここでは, PDG の臨床評価における有効 性と作用特性について, 新規育毛有効成分の事例として 紹介する。

\subsection{PDG の臨床評価における有効性}

武田ら ${ }^{43)}$ は男性型脱毛症に対する PDG 配合製郕の 有用性を評価するため, 155 名の被験者による臨床試験 を二重盲検群間比較法により行った。被験者は $2.5 \%$ PDG および $0.2 \% \alpha$-トコフェロール配合製剂(LHOP) または対照剂（LHOP から PDG のみを除いた製剤） のいずれか一方を $1 \mathrm{~d} 2$ 回, 24 週間, 前頭部から頭頂部 へ塗布した。前者をアクティブ群, 後者をコントロール 群とし, 改善度や有用度等の評価結果が解析された。そ の結果, 軟毛 (vellus hair) の発生, 軟毛から硬毛 (terminal hair) への変化等の毛髪所見をもとにした改善 度評価において, アクティブ群はコントロール群に比べ て高い改善率を示した。副作用は試験期間中を通じて両 群とも全く認められなかった。試験終了時の有用度評価 の結果 (Table-2) では, アクティブ群の有用率は 76.0 \%であったのに対してコントロール群は $32.0 \%$ で, 群 間に統計的有意差が認められた。

本臨床試験では改善度評価の参考のための定量的評価 法として成長期毛数の計測が実施された。前頭部の生え

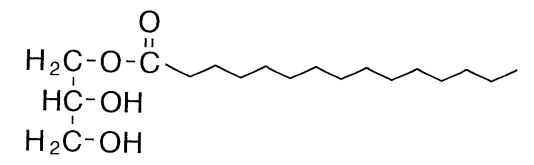

Fig.-6 Chemical structure of 1-monopentadecanoyl glycerol (PDG). 
Table-2 Effect of PDG in treating male pattern baldness.

(Number of subjects)

\begin{tabular}{l|c|c|c|c|c}
\hline & $\begin{array}{c}\text { Most } \\
\text { preferable }\end{array}$ & $\begin{array}{c}\text { Very } \\
\text { preferable }\end{array}$ & $\begin{array}{c}\text { Moderately } \\
\text { preferable }\end{array}$ & $\begin{array}{c}\text { Non- } \\
\text { commital }\end{array}$ & Total \\
\hline Active & 1 & 15 & 41 & 18 & 75 \\
\hline Control & 0 & 3 & 21 & 51 & 75 \\
\hline
\end{tabular}

Statistically significant in Mann-Whitney's U-test, $p=0.000$

[Percentage of improved subjects] Active, $76.0 \%$; Control, $32.0 \%$

[Clinical findings]

Appearance of vellus hair : Active, $45.3 \%$; Control, $24.0 \%$

Vellus hair $\rightarrow$ Terminal hair : Active, $62.7 \%$; Control, $22.7 \%$

[Adverse effects] not seen in all subjects.

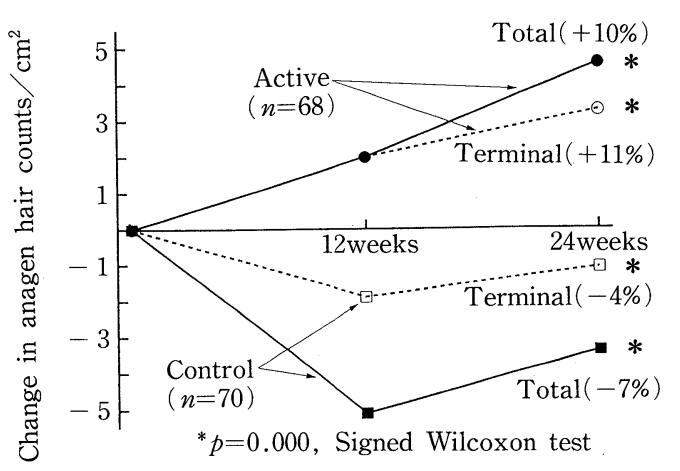

Fig.-7 Effect of PDG on anagen hair count.

ぎわ付近の特定部位を剃毛し, $3 \sim 5 \mathrm{~d}$ 後に拡大写真を 撮影して苟毛後に伸長した成長期毛数を測定するという 方法が用いられた。その結果, コントロール群では試験 開始時に比べ減少を示したのに対し，アクティブ群では 経時的に増加を示した (Fig. -7)。

これらの結果から, PDG は男性型脱毛症に対して安 全で高い有効性を有するものであることが示された。

\subsection{PDG の作用特性}

正常な毛包では，主要エネルギー源は血流からのグル コースと毛包中のグリコーゲンであると考えられる。こ れらは解糖系 $\rightarrow \mathrm{TCA}$ サイクルという経路を経て代謝さ れ, 高エネルギー物質であるアデノシン三リン酸 (ATP) が産生される。しかしながら, 男性型脱毛症の 毛包では，このエネルギー代謝系が抑制されていること が知られている。そこで著者らは，毛包のエネルギー代 謝, 特に ATP 産生に対する PDGの作用を検討した。

PDG はウサギに対して優れた育毛効果を示す22),37) ことから, ウサギ毛包の ATP 量に対する PDG 塗布の 影響を調べた。へアサイクルが成長期または休止期に変 換した直後のウサギの背部を剪毛し, PDG を週 5 回, 4 週間塗布した後，毛包を抜去して ATP 量を測定した。 その結果, 成長期では休止期に比べて ATP 量が高く,

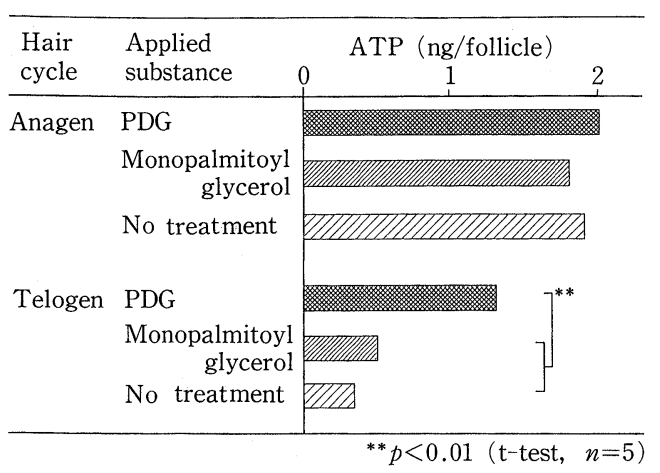

Fig.-8 Effect of PDG on ATP level in rabbit hair follicles.

PDG 塗布の影響は認められなかったが，休止期では PDG 塗布により ATP 量が顕著に増加した ${ }^{44), 45) ~}$ (Fig.-8)。このことは，エネルギー代謝が抑制された 休止期の毛包に対する PDG のエネルギー供給作用を示 すものである。

この作用を細胞レベルで確認するため, 毛乳頭の細胞 培養系における検討を行った。ラット vibrissa 毛包か ら単離培養した毛乳頭由来細胞を用い, 細胞増殖の主要 エネルギー源であるグルコースなどを除いた抑制培地 に, 代替エネルギー源としてペンタデカン酸 $(\mathrm{PDA})$ を 加えた場合の影響について調べた。その結果, PDA の 添加により細胞中の ATP 量および DNA 合成能 $\left({ }^{3} \mathrm{H}-\right.$ Thy 取り込み量) の上昇が見られた ${ }^{37), 45)}$ (Fig.-9, 10)。このことは，エネルギー代謝が抑制された状態の 毛乳頭細胞に対する PDG の活性化作用を示すものであ る。

これらの研究の結果から, PDG の作用メカニズムは 以下のように考えられる。男性型脱毛症の毛包ではエネ ルギー代謝系, 特に解糖系が抑制されており, グルコー スやグリコーゲンに代わって脂肪酸が主要エネルギー源 として使われる。偶数脂肪酸は $\beta$-酸化により代謝され 


\begin{tabular}{|c|c|}
\hline Medium & $\underset{1}{\operatorname{ATP}}\left(\times 10_{2}^{-10} \mathrm{~mol} / \mathrm{dish}\right)$ \\
\hline Complete medium & 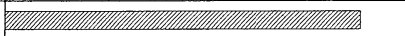 \\
\hline $\begin{array}{l}\text { Suppressed medium } \\
+\mathrm{PDA}(48 \mu \mathrm{M})\end{array}$ & 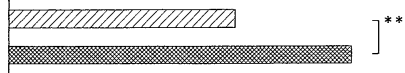 \\
\hline
\end{tabular}

Fig.-9 Effect of pentadecanoic acid (PDA) on ATP production in cultured dermal papilla cells.

\begin{tabular}{|c|c|c|}
\hline Medium & 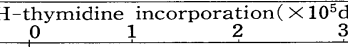 & $\mathrm{dpm} / \mathrm{dish}$ \\
\hline Complete medium & 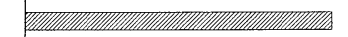 & \\
\hline $\begin{array}{l}\text { Suppressed medium } \\
\quad+\operatorname{PDA}(48 \mu \mathrm{M})\end{array}$ & $\mathrm{m}$ [IIIIIIIIIIIIIA & $7^{* *}$ \\
\hline
\end{tabular}

Fig.-10 Effect of pentadecanoic acid (PDA) on DNA synthesis in cultured dermal papilla cells.

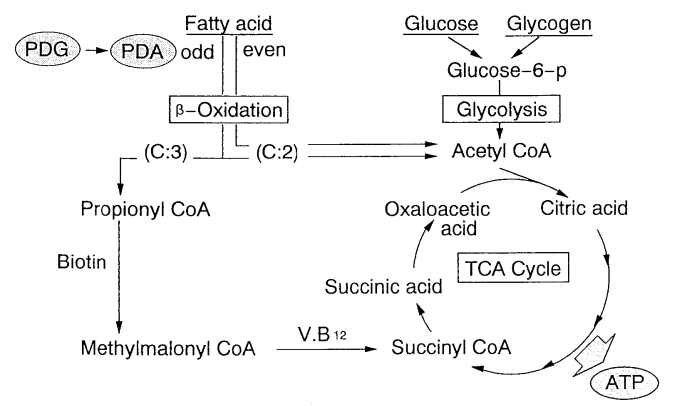

Fig.-11 Metabolic pathway of PDG on energy production.

てアセチル CoA のみを生じるが, 奇数脂肪酸は $\beta$-酸化 の最後にプロピオニル CoA を生じる。プロピオニル $\mathrm{CoA}$ はメチルマロニル CoA を経てスクシニル CoA と なり, TCA サイクルに入ってコハク酸に変換される。 この奇数脂肪酸の代謝経路 $($ Fig.-11) が毛包にも存在 すること，そしてコハク酸が ATP 産生を促進すること を，モルモット毛包ミトコンドリアを用いた研究44),45) で確認している。つまり, PDG は奇数脂肪酸の代謝特 性に基つくくメカニズムによって毛包に効率的にエネル ギーを供給し，エネルギー産生が抑制された男性型脱毛 症の毛包を活性化することによって，優れた育毛作用を 発揮すると考えられる。

\section{7 おりに}

以上, 毛の成長とヘアサイクル, 男性型脱毛症とその 原因, 育毛剂の有効成分, 育毛効果の評価法について概 説し, 最後に新規有効成分の事例として PDG の育毛作 用について紹介した。

毛の成長あるいは男性型脱毛症に関する基礎的研究は
これまでのところ充分な進展を見せておらず，メカニズ ムはほとんど解明されていないと言える。そのため従来 の育毛剂は血流改善剂や栄養補給剤等を配合したものが 大半を占めていた。しかし近年は細胞培養等の技術の進 歩に伴う細胞レベルでの研究の進展により，新たな明確 な狙いを持つ育毛成分の開発が盛んに試みられている。

今後さらに, 毛の成長やへアサイクルの制御機構の解 明, 男性ホルモンの作用機構 (レセプター結合, 遺伝子 発現等）の解明などを目指した基礎的研究を積み重ねる ことによって，より顕著な作用を持つ育毛有効成分の開 発が実現していくものと思われる。

〔平成 7 年 (1995 年) 1 月 9 日受理〕

\section{文献}

1）上野賢一, “小皮虑科書”, 金芳堂 (1987) p. 10

2) G.D. Weinstein, K.M. Mooney, J. Invest. Dermatol., 74, 43 (1980)

3) 山村雄一ら, “現代皮膚科学大系 $3 \mathrm{~A}$ ”, 中山書店 (1982) p. 171

4) R.F. Oliver, J. Embryol. Exp. Morphol., 23, 219 (1970)

5) C.A.B. Jahoda, K.A. Horne, R.F. Oliver, Nature, 311, 560 (1984)

6) S. Arase et al., J. Dermatol., 17, 667 (1990)

7) Y. Hirai et al., Cell, 69, 471 (1992)

8）神藤敏正ら, 日本皮膚科学会誌, 103, 351 (1993)

9) 緒方知三郎, 総合臨床, 2, 101 (1953)

10) J.B. Hamilton, Recent Progr. Horm. Res., 3, 257 (1948)

11) C. Sultan, K. Bakkar, A.J.M. Vermorken, "Trends in Human Hair Growth and Alopecia Research", Kluwer Academic Publishers (1989) p. 89

12) R. Choudhry et al., J. Endocrinol., 133, 467 (1992)

13) V.A. Randall et al., J. Invest. Dermatol., 98, $86 \mathrm{~S}$ (1992)

14) S. Itami et al., J. Invest. Dermatol., 96, 57 (1991)

15) S. Itami et al., Ann. N.Y. Acad. Sci., 642, 385 (1991)

16）堀田寿夫，日皮協ジャーナル， 8, 15 (1982)

17) W.S. Bullough, E.B. Laurence, "The biology of hair growth", Academic Press, New York (1958) p. 171

18) K. Adachi et al., J. Soc. Cosmet. Chem., 21, 901 (1970)

19）渡辺 靖, 日本香粧品科学会誌, 6, 9 (1982)

20）長谷川健二, 政本幸三, 日本皮膚科学会誌, 95, 771 (1985)

21）大場健吉, Frangrance Journal, 14 (5), 109 (1986)

22) K. Oba, Cosmetics \& Toiletries, 103 (5), 69 (1988)

23）大場健吉, 玉井秀夫, Fragrance Journal, 17 (5), 85 (1989)

24) D.W. Frederiksen, J.D. Wilson, J. Biol. Chem., 246, 2584 (1971)

25) V.A. Randall, M.J. Thornton, A.G. Messenger, J. Endocrinol., 133, 141 (1992)

26) M. Hattori, H. Ogawa, J. Dermatol., 10, 45 (1983) 
27) A.G. Messenger, Brit. J. Dermatol., 110, 685 (1984)

28) C.A.B. Jahoda, R.F. Oliver, J. Embryol. Exp. Morphol., 79, 211 (1984)

29）渡辺信他，日本皮虑科学会誌，94，1631 (1984)

30) P. Hawley-Nelson et al., J. Invest. Dematol., 75, 176 (1980)

31) S. Arase et al., J. Dermatol. Sci., 2, 66 (1991)

32) 藤江建志ら，日本皮膚科学会誌，103，907 (1993)

33) R. Frater, P.G. Whitmore, J. Invest. Dermatol., 61, 72 (1973)

34) S. Kondo, Y. Hozumi, K. Aso, Arch. Dermatol. Res., 282, 442 (1990)

35）小川秀興, 今井龍介, Fragrance Journal, 17 (5), 20 (1989)

36）山村達郎，正木 仁，左近健一，日本皮䖉科学会誌，
102, 203 (1992)

37) 足立邦明, Fragrance Journal, 21 (9), 50 (1993)

38) H. Rushton, K.C. James, C.H. Mortimer, Brit. J. Dermatol., 109, 429 (1983)

39) E.A. Olsen et al., J. Am. Acad. Dermatol., 13, 185 (1985)

40） LKF-A 研究班，西日本皮膚科，48，738 (1986)

41) S. Hayashi, I. Miyamoto, K. Takeda, Brit. J. Dermatol., 125, 123 (1991)

42) 石野章博ら，日本皮虨科学会誌，101，326 (1991)

43）武田克之ら, 西日本皮膚科, 55, 727 (1993)

44) K. Adachi et al., International J. Cosmet. Sci., 15, 125 (1993)

45) D. Yokoyama et al., Abstracts of AOCS-JOCS Joint Meeting 1993, (Anaheim), p.480 (1993) 